\title{
Achievement of Climate Planning Objectives among US Member Cities of the International Council for Local Environmental Initiatives (ICLEI)
}

\author{
Margaret A. Reams, Kelsey W. Clinton, Nina S. N. Lam \\ Department of Environmental Sciences, Louisiana State University, Baton Rouge, USA. \\ Email:mreams@lsu.edu
}

Received September $11^{\text {th }}$, 2012; revised October $13^{\text {th }}$, 2012; accepted October $28^{\text {th }}, 2012$

\begin{abstract}
In an effort to address climate change, many cities have joined the International Council for Local Environmental Initiatives (ICLEI) whose members commit to work toward five specific program objectives designed to reduce greenhouse gas emissions. This study examines the extent to which 257 member cities in the US have been successful in achieving these program milestones and identifies factors that may explain variation in the performance of member cities. Potential influences on milestone attainment include socioeconomic, political and ideological characteristics of residents, length of ICLEI membership, existence of other climate programs within the state, and local environmental pressures. Multiple regression results indicate that length of membership is the strongest predictor of milestone attainment, regardless of local socioeconomic conditions, ideological and political orientations of residents, or other climate-related initiatives within the state. This finding supports the general effectiveness of ICLEI's network organizational model and its outreach and education efforts. However, member cities facing more "climate stress", including higher levels of hazardous air pollutants (HAP's) and greater automobile use among residents are making slower progress. The findings yield insight into the conditions under which cities engaged in climate planning are more likely to succeed in reducing local greenhouse gas emissions-relevant information for planners, community stakeholders and administrators of organizations like ICLEI.
\end{abstract}

Keywords: Greenhouse Gas Reduction; Local Climate Initiatives; Climate Planning; Climate Organizations; ICLEI

\section{Introduction}

While national and international climate-change policy options continue to be debated, many cities are addressing the issue locally. Formulating local greenhouse gasreduction plans may be especially desirable since local control allows cities to choose measures best suited to them [1-3]. However, some local plans may be more symbolic in nature with large reduction targets not set to be reached until 2040 or 2050, long after the officials who signed the plans are out of office [4]. Thus, questions may be raised as to how effective city-level actions really are-specifically, to what extent are cities making progress toward stated greenhouse gas-reduction goals?

The objectives of this research are two-fold: to examine the number of International Council for Local Environmental Initiatives (ICLEI) program milestones met by 257 member cities in the US, and to identify key factors that may explain variation in attainment of these program objectives. While previous research has examined influences on local efforts to address climate change, includ- ing decisions to join network-type alliances and to adopt climate-action plans [5-7], this analysis will focus on the achievement of specific greenhouse gas-reduction milestones as specified by ICLEI. The findings provide insights into the effectiveness of ICLEI and the conditions under which member cities are more likely to achieve long-term reductions in greenhouse gases. Thus, the results have implications for policy makers and community stakeholders interested in climate planning at the local level, and for groups like ICLEI concerned with how best to support the efforts of a diverse set of cities.

Specifically, we will address three questions:

1) Are member cities with affluent and well-educated residents more likely to achieve ICLEI program milestones for climate planning?

2) Are member cities facing greater environmental pressures less likely to achieve program milestones?

3) Are member cities whose residents are more liberal and hold more pro-environmental attitudes more likely to attain ICELI program milestones? 


\subsection{The International Council for Local Environmental Initiatives (ICLEI)}

The International Council for Local Environmental Initiatives (ICLEI) began in 1989 and helps local governments formulate and implement plans to reduce greenhouse gas emissions. As of 2012, ICLEI has over 1200 member cities worldwide, with 600 located in the US [8]. Members commit to work toward the achievement of five sequential climate planning objectives: 1 ) conduct a local greenhouse gas emissions inventory; 2) adopt emission-reduction targets; 3) develop a local climate-action plan; 4) implement the plan; and 5) monitor and verify the results [9].

Membership in ICLEI signals the intention to reduce carbon emissions, and entitles cities to receive a range of services and technical support from the organization. For example, ICLEI provides information and assessment tools for conducting emissions inventories and determining reduction targets for Milestones 1 and 2. The assistance includes statistical software and training to track and analyze trends in local emissions, and access to regular webinars addressing climate topics. Building on this network, ICLEI is expanding its educational and technical assistance beyond mitigation to include adaptation to climate change, including strategies to protect public health and safety in the event of extreme weather events [9].

ICLEI member cities in the US are found throughout the country, with many members along the East and West coasts. A cluster of member cities are observed around Puget Sound in the state of Washington, the San Francisco Bay area in coastal California, and along the Washington DC-New York City-Boston corridor. Member cities also are found in the upper Midwest section of the country in the Great Lakes states, the upper South, and several mountain states-regions not traditionally considered to be interested in climate planning $[1,10]$.

\subsection{Cities and Climate Planning}

Over half of the world's population live in urban areas, and many of the activities associated with greenhouse gas emissions emanate from cities [11,12]. In the US $82 \%$ of all residents live either in cities or in surrounding suburban areas [13]. City leaders can affect greenhouse gas emission levels through a range of decisions concerning energy supply and management, transportation and land-use planning, building code adoption, and waste-management practices within their jurisdictions [14]. This creates the opportunity for local officials to choose climate actions that are consistent with the needs and preferences of residents, and administrative capabilities of the city [15].
Many climate-related programs and actions are relatively easy to implement and can result in multiple benefits to cities. For example, hybrid vehicles and LED lighting, which may cost more at first, are more efficient and use less energy than traditional vehicles and lights, leading to lower municipal energy costs [16,17]. In addition, local efforts to reduce greenhouse gas emissions can be framed as also addressing problems like air pollution and urban sprawl. In this sense, climate planning may include a range of "no-regrets" actions that yield costsavings and benefits in addition to those associated with climate-change mitigation [18].

The potential greenhouse gas reductions from local actions are significant. Recently, Lutsey and Sperling calculated that if all of the state and city emissions targets in place were to be achieved, US emissions could be stabilized at 2010 levels as soon as 2020 [19]. This would be a substantial reduction in greenhouse gases and could be accomplished without federal mandates.

\section{Related Research}

Local leaders and community stakeholders seeking to formulate and implement greenhouse gas reduction programs face a range of challenges. Betsill [16] identified several disincentives, including that local decision makers may be discouraged by the magnitude of the problem, and the realization that cities will be affected by climate change regardless of local efforts. Also, the collective benefits of mitigation will go to both participating and non-participating cities, introducing a potential "free rider" problem. In addition, there is no significant federal assistance for climate-change planning, and many localities are facing significant budget limitations. Further, Wiener posits that local action even could have a negative effect on limiting overall $\mathrm{CO}_{2}$ emissions within an area if one city's more stringent guidelines push some industries into other areas with lesser standards. This "leakage" could lead to increased $\mathrm{CO}_{2}$ emissions within the larger area [20]. These factors and considerations may tend to discourage city leaders to commit time and scarce public resources to activities that may have little measurable effect on climate change in their region.

Given these challenges, what factors influence cities to adopt greenhouse gas-reduction programs? Krause examined general commitment to climate planning through construction of the "municipal climate-protection index", based on the existence of greenhouse gas inventories, broad energy efficiency measures, and "green development" and transportation initiatives [4]. This index builds on previous studies by Portney [7] and Lubell, Feiock, and Handy [21] that measured commitment to goals of overall sustainability. He found that cities more committed to climate planning tend to have larger populations, better 
educated citizens, Democratic-party political leanings, and often a climate policy "entrepreneur" or advocate within the local government.

Similarly, ICLEI member cities tend to have residents who are affluent, well educated, hold more liberal political views, are active in community organizations and more concerned with environmental issues. Also, cities with colleges or universities and those with local government ownership of electric utilities have been found to be more likely to join ICLEI [5,22-24]. In addition, cities that have addressed other environmental issues through public policies and collective actions are more likely to have environmentally minded citizens [25], and have been found to be more likely to join ICLEI [16]. Also, decisions to join organizations like ICLEI may be influenced further by perceived benefits such as enhancement of reputations for environmental awareness and stewardship $[16,22]$. Factors that may discourage ICLEI membership include more "climate stress", specifically having more of the local population employed in carbon-related industries, more residents driving alone to work, and higher levels of hazardous air pollutant emissions per capita $[23,26]$.

While these previous studies shed light on city leaders' decisions to engage in local climate planning and join ICLEI, fewer have examined achievement of ICLEI program milestones once cities become members. One analysis conducted by Pitt [24] found that cities are more likely to meet ICLEI program objectives if their residents have higher levels of general environmental concern, if they have assigned city government staff members working on climate issues, and if they are located near other cities involved in local climate planning. Pitt also found that factors associated with ICLEI membership, including education and income of residents, voting history and college-town status; appear to have little to no influence on a city's progress toward meeting ICEI's program milestones. Similarly, Sharp et al. [1] examined factors that may influence both membership in ICLEI and achievement of program milestones. They looked at a group of ICLEI cities with populations larger than 100,000 and found that factors that appear to encourage ICLEI membership are not the same as those associated with achievement of program objectives. The strongest predictor of achievement of program milestones was found to be the length of ICLEI membership.

\section{Data \& Methods}

In the US, over 600 cities and municipalities have joined ICLEI. This analysis includes all US member cities with populations of at least 20,000 and who joined before 2009. The rationale for excluding more recent ICLEI members is to allow some lag time for achievement of program milestones. Member cities with fewer than 20,000 residents were not included because their small size makes it difficult to collect accurate data since they are classified differently in different states, i.e. as townships or villages. This resulted in 257 cities across 40 states being included in the study.

\subsection{Dependent Variable-ICLEI Milestones}

The dependent variable is the number of milestones achieved by the ICLEI member cities by December of 2011. As stated previously, the milestones are: 1) conduct a local greenhouse gas emissions inventory; 2) adopt emission-reduction targets; 3) develop a local climate-action plan; 4) implement the plan; and 5) monitor and verify the results [9]. The cities' milestone achievements are compiled from the ICLEI Member List and the 2010 Annual Report. ICLEI allows the members to determine whether the five milestones will be applied to city government operations only, the general community, or both.

\subsection{Independent Variables}

The analysis includes thirteen independent variables divided into three groupings adapted from Zahran et al. [23]: socioeconomic, climate change stress, and political and ideological orientation. The variables included in each category are described briefly below.

Socioeconomic variables: Percent with bachelor's degree refers to those over age 25 who have a bachelor's degree or higher; Percent unemployed are those without jobs within the civilian labor force; percent poverty refers to residents whose income for the last 12 months was below the U.S. federal poverty level; Median income is the median household income; and population is simply the total number of residents in a city. The socioeconomic variables were taken from the 2005-2009 American Community Survey 5-Year Estimates [27].

Climate-Change Stress: The variable, percent carbon employment measures the percentage of residents 16 years or older who are employed in carbon dioxide intensive industries such as construction, agriculture, mining, manufacturing, utilities, and transportation. This information was obtained from the 2005-2009 American Community Survey 5-Year Estimates [27]. Hazardous Air Pollutant (HAP) emissions are useful data to consider because cities with poorer air quality may be more reliant on carbon-intensive industries, but they also have an incentive to reduce these pollutants in order to improve local air quality. To measure HAP emissions the total amount of HAP emissions for each city were obtained from the EPA's AirData website [28]. This amount was then divided by the number of residents of each city in order to compare emissions per capita between cities. Car 
dependency is the percentage of workers 16 years and older that commute to work alone in a car, van, or truck. Population density data divides the total population of the city by the land area. The population density is relevant to energy use levels and transportation patterns in a city. The data for this variable and car dependency came from the 2005-2009 American Community Survey 5Year Estimates [27].

Local Attitudes: The general category of "local attitudes" includes indicators of the political ideology of residents within a city. While Zahran et al. [23] placed some of these variables into the "civic capacity" category, for this study a general category called "local attitudes" has been created because the variables may be seen as a reflection of the political preferences and ideology of local residents. The environmental nonprofits variable indicates awareness of and support for various environmental issues. The environmental non-profit data was collected from the National Center for Charitable Statistics [29] and then divided by the number of residents in a city to allow for comparison across cities. The NCCS collects data on non-profits that are tax-exempt, have more than $\$ 25,000$ in gross receipts, and are required to file Form 990 with the Internal Revenue Service.

State initiatives regarding climate change is included in the analysis since the trends that appear at the state level may be associated with local programs and residents' attitudes toward climate change mitigation. Information compiled by the Pew Climate Center was used to construct this variable [30]. The Pew Center added all state actions in the categories of climate action, energy sector, transportation, and the building sector. Within these categories are 28 separate initiatives including participating in regional efforts like the Western Climate Initiative and the Regional Greenhouse Gas Initiative, and adopting state targets and guidelines for greenhouse gas reduction, renewable energy portfolio standards, lowcarbon fuels, green building standards, and others. No state has completed all 28 actions, but four states have completed 26 of them. We gave each city in this study a score based on the number of initiatives completed by their state. For instance, each city is California received a score of 26 since the state has implemented 26 climate measures.

Political affiliation was measured by the percentage of residents who voted for President Obama in the 2008 election, according to the New York Times Election Results Map. This map [31] shows the election results by county, and that county number was used for each city within the county. This \% vote for Obama variable is an estimate of Democratic Party supporters at the time.

Years in ICLEI also may be considered a measure of local attitudes, since the early-joining cities of the 1990's had the support of local residents relatively early in the climate-change policy debate in the U.S., a debate that gained momentum following the Kyoto Protocol of 1997. This variable comes from the member list on ICLEI websites [8,9], and is measured as the number of years that a city has been an ICLEI member. The first US members joined ICLEI in 1991, and the last cities in this study joined in 2008, so this value ranges from 1 to 17 years.

\subsection{Statistical Analysis}

Step-wise multiple regression analysis in the statistical software package SPSS 15.0 was used to identify independent variables significantly associated with the dependent variable, number of ICLEI program milestones achieved. The analysis also determines the relative influence of each independent variable found to be significantly associated with milestone achievement.

\section{Results and Discussion}

To what extent have the 257 member cities achieved ICLEI program milestones? Figure 1 provides an overview of milestone achievement. One-hundred-ten of the cities have not completed any milestones, and 36 have attained only one. Fifty-eight cities have reached Milestone 3, to "Develop a Local Climate Action Plan”, with a total of 31 having implemented their plans. Of these 31 cities, 21 have met the final milestone of evaluating the local climate plan. The cities that have reached milestones 4 and 5 are considered to be making more progress toward reducing greenhouse gas emissions.

The Milestone 5 cities are generally larger cities that have reputations for strong environmental protection efforts, such as San Francisco, California, Portland, Oregon and Seattle, Washington. The ten cities that have reached milestone 4 are somewhat smaller cities that are not as well-known, but they still have "green" reputations, with several having been recognized as leaders in sus-

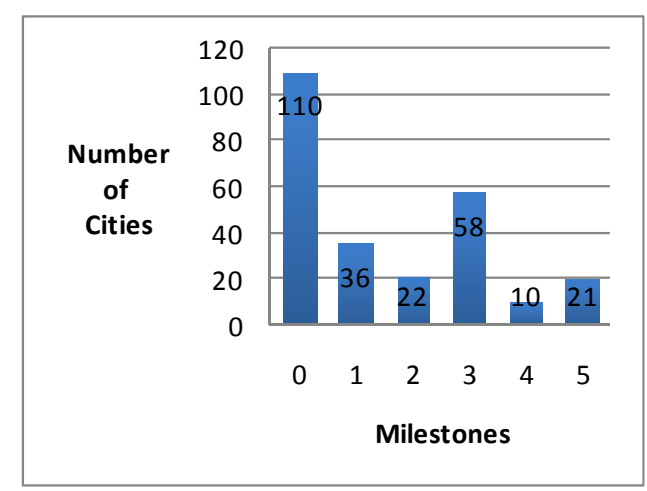

Figure 1. Milestone completion among 257 cities. 
tainability planning [7].

\subsection{Multiple Regression Analysis Results}

We conducted multiple regression analysis to determine the relative influence of socioeconomic, political and attitudinal characteristics of residents and climate-stress factors on achievement of ICLEI program milestones. Using the stepwise method, three independent variables were found to be correlated with the dependent variable and were entered into the model: years in ICLEI, HAP emissions, and car dependency. The analysis yielded an adjusted R-squared value of 0.316 , indicating that that these three independent variables together account for almost $32 \%$ of the variation in milestone achievement among the 257 cities. The number of years of membership in ICLEI explains most of the variation in milestone achievement with a standardized regression coefficient (beta) value of 0.460 , followed by HAP emissions at -0.163 and car dependency at -0.134 . The results of the analysis are summarized in Table $\mathbf{1 .}$

\subsection{Discussion of Results}

Question 1: Are member cities with affluent and welleducated residents more likely to meet ICLEI program milestones for climate planning? The results of the regression analysis do not offer evidence of a significant association between socioeconomic attributes of residents of member cities and achievement of ICLEI program milestones. None of the independent variables measuring affluence, employment rate or education levels were found to be significantly associated with the dependent variable, milestone achievement. These findings confirm some of Pitt's [24] results, specifically, that the factors that help predict ICLEI membership do not explain which cities will be more successful in meeting program milestones after they join the organization.

Question 2: Are member cities facing greater environmental pressures less likely to attain program milestones? The findings offer evidence that cities facing more climate

Table 1. Influences on climate milestone completion.

\begin{tabular}{cccccc}
\hline & \multicolumn{2}{c}{$\begin{array}{c}\text { Unstandardized } \\
\text { Coefficients }\end{array}$} & $\begin{array}{c}\text { Standard } \\
\text { Coefficients }\end{array}$ & t & P value \\
\cline { 2 - 5 } & $\mathbf{B}$ & Std. Error & Beta & & \\
\hline Constant & 2.620 & 0.662 & & 3.958 & 0.000 \\
$\begin{array}{c}\text { Years in } \\
\text { ICLEI }\end{array}$ & 0.198 & 0.024 & $\mathbf{0 . 4 6 0}$ & 8.325 & 0.000 \\
$\begin{array}{c}\text { HAP } \\
\text { Emissions }\end{array}$ & -0.001 & 0.000 & $\mathbf{- 0 . 1 6 3}$ & -3.109 & 0.002 \\
$\begin{array}{c}\text { Car } \\
\text { Depend }\end{array}$ & -0.021 & 0.009 & $\mathbf{- 0 . 1 3 4}$ & -2.419 & 0.016 \\
\hline
\end{tabular}

R squared $=0.324$; Adjusted R squared = 0.316; $\mathrm{N}=257$. stress have made less progress toward achieving ICLEI program milestones. Specifically, two indicators of environmental pressures, HAP emissions and car dependency, were found to be inversely associated with milestone attainment. This suggests that progress toward greenhouse gas reduction is slower in member cities with higher HAP emissions and more automobile use among residents. The findings are not surprising and are similar to Sharp and his colleagues' finding that more manufacturing and industrial activities in a city are linked to lower ICLEI milestone achievement [1].

This study is the first to identify car dependency as a significant (inverse) predictor of achievement of greenhouse gas reduction milestones under ICLEI. The car dependency variable conveys information about potential road congestion, gasoline use, and the extent to which residents have invested in public transportation, bicycle lanes and pedestrian walk ways. A city whose residents are more reliant on personal vehicles as the main mode of transportation may have more difficulty in implementing local climate change plans and ultimately in making progress in limiting greenhouse gas emissions.

Question 3: Are member cities whose residents are more liberal and hold more pro-environmental attitudes more likely to attain ICELI program milestones? The findings offer evidence that public attitudes are related to progress toward reducing greenhouse gases. The most important variable in this model is years in ICLEIwithout this variable the regression results explain only a very small percentage of the variance. This indicates that cities that have been an ICLEI member longer tend to have completed more milestones than cities that joined more recently. The finding is consistent with that of Sharp et al. [1] in their study of a smaller group of ICLEI cities, those with more than 100,000 residents. It is not surprising, since a city that joined in the 1990's has had more time to reach more milestones. There are some cities that joined more recently and yet have completed an impressive number of milestones, such as Bellingham, WA, which joined in 2007 and had attained four milestones by the end of 2008. However, this rapid achievement of program milestones is unusual among member cities.

While other indicators of the political preferences of the local voters, including support for President Obama in the 2008 presidential election and the presence of more environmental nonprofit groups and climate-related state initiatives were not found to be linked to milestone attainment, the length of membership in ICLEI is a clear indicator of public support for climate planning. As stated earlier, Years in ICLEI is indicative of local attitudes, since the early-joining cities of the 1990's had the support of local residents relatively early in the climatechange policy debate in the U.S. In the context of this 
self-evident local support and interest, the outreach and technical assistance offered by ICLEI to these member cities has led to measurable progress toward the program milestones to reduce greenhouse gas emissions.

These results confirm and expand upon some of the previous research concerning local government efforts to reduce greenhouse gas emissions. The findings suggest that the influences on achievement of ICLEI milestones for greenhouse gas reduction are different from those that may influence a city to join ICLEI. Whereas socioeconomic and civic capacity variables are the strongest predictors of ICLEI membership [22,23], climate-stress factors and length of membership within the organization appear to be more important in explaining variation in achievement of ICLEI milestones. Specifically, length of membership in ICLEI is positively associated with milestone completion, while the other two variables were found to have inverse associations, suggesting that a higher level of climate stress may hinder a city's ability to make progress toward meeting the program's greenhouse gas reduction milestones.

\section{Conclusions}

The International Council for Local Environmental Initiatives (ICLEI) encourages cities to commit to a path of action to address climate change at the local level. Cities that are committed to ICLEI can help reduce greenhouse gas emissions, especially as more cities join and advance in milestone achievement. This analysis yields insight into the conditions under which those cities that have joined ICLEI and made a public commitment to work toward greenhouse gas reduction are more likely to make progress toward that goal. The study examined a larger and more diverse group of ICLEI member cities-257 cities with populations of at least 20,000 - than the earlier study by Sharpe, et al. [1].

Multiple regression analysis indicates that cities that have been members for more years are much more likely to progress toward achievement of program objectives, regardless of socioeconomic or political factors-a finding that supports the general effectiveness of ICLEI's network organizational model and its outreach and education efforts. This is good news for ICLEI as it indicates that member cities benefit from the technical assistance and support that the organization makes available; the program's outreach and provision of technical support appear to be working.

The findings also indicate that local environmental conditions matter, with more sources of "climate stress" such as greater automobile dependency introducing significant challenges to progress toward greenhouse gas reduction objectives. Patterns of car dependency and levels of hazardous air pollution reflect aspects of local history, economic development, and land-use planningand, as such, are not easy to change. However, insights into these challenges are useful to programs like ICLEI, whose administrators could devise targeted programs for member cities facing higher levels and more sources of climate stress. For example, member cities with higher automobile dependency could be provided additional information concerning planning and financing of expanded public transportation systems. Also ICLEI could encourage and facilitate increased communication among member cities facing similar environmental pressures. In addition, case studies of cities whose planners and residents have made progress toward greenhouse gas reduction in the context of these and other climate stresses would be valuable to those still working to devise and implement local climate plans.

While local conditions and activities that produce climate stress are varied, complex and difficult to change quickly, ICLEI should be able to identify member cities facing greater environmental pressures and provide targeted assistance to help them make progress toward longterm greenhouse gas reductions.

\section{Acknowledgements}

This research was supported in part by a joint grant from the National Science Foundation (NSF) and the US Department of Agriculture (USDA), Federal Award Number: USDA 2010-65401-21312.

\section{REFERENCES}

[1] E. B. Sharp, D. M. Daley and M. S. Lynch, "Understanding Local Adoption and Implementation of Climate Change Mitigation Policy," Urban Affairs Review, Vol. 47, No. 3, 2011, pp. 433-457. doi:10.1177/1078087410392348

[2] N. J. Toly, "Transnational Municipal Networks in Climate Politics: From Global Governance to Global Politics,” Globalizations, Vol. 5, No. 3, 2008, pp. 341-356. doi:10.1080/14747730802252479

[3] G. Lindseth, "The Cities for Climate Protection Campaign (CCPC) and the Framing of Local Climate Policy," Local Environment, Vol. 9, No. 4, 2004, pp. 325-336. doi:10.1080/1354983042000246252

[4] R. M. Krause, "Symbolic or Substantive Policy? Measuring the Extent of Local Commitment to Climate Protection," Environment and Planning C: Government and Policy, Vol. 29, No. 1, 2011, pp. 46-62. doi:10.1068/c09185

[5] M. R. Boswell, A. I. Greve and T. L. Seale, “An Assessment of the Link between Greenhouse Gas Emissions Inventories and Climate Action Plans," Journal of the American Planning Association, Vol. 74, No. 4, 2010, pp. 451-462. doi:10.1080/01944363.2010.503313

[6] R. C. Feiock, N. Francis and T. Kassekert, "Explaining 
the Adoption of Climate Change Policies in Local Government," Pathways to Low Carbon Cities Workshop, Hong Kong, 2010, unpublished.

[7] K. E. Portney, “Taking Sustainable Cities Seriously: Economic Development, the Environment, and Quality of Life in American Cities,” MIT Press, Cambridge, 2003.

[8] ICLEI USA, “Climate Adaptation Guidance,” 2012. http://www.icleiusa.org/climate_and_energy/Climate_Ad aptation_Guidance/

[9] ICLEI USA, "Empowering Sustainable Communities: ICLEI USA Annual Report 2010,” 2010. http://www.icleiusa.org/about-iclei/annual-reports

[10] B. Rabe, "Racing to the Top, the Bottom, or the Middle of the Pack? The Evolving State Government Role in Environmental Protection,” In: S. Schneider, A. Rosencranz and J. Niles, Eds., Climate Change Policy: A Survey, 7th Edition, Island Press, Washington DC, 2012, pp. 27-50.

[11] M. M. Betsill, "Mitigating Climate Change in US Cities: Opportunities and Obstacles," Local Environment, Vol. 6, No. 4, 2001, pp. 393-406. doi:10.1080/13549830120091699

[12] N. J. Toly, “Transnational Municipal Networks in Climate Politics: From Global Governance to Global Politics,” Globalizations, Vol. 5, No. 3, 2008, pp. 341-356. doi:10.1080/14747730802252479

[13] Central Intelligence Agency, "The World Factbook," 2012.

http://www.cia.gov/library/publications/the-world-factboo k/fields/2212.html

[14] H. Bulkeley, "Cities and Climate Change: Urban Sustainability and Global Environmental Governance,” Routledge, London, New York, 2003.

[15] G. Lindseth, "The Cities for Climate Protection Campaign (CCPC) and the Framing of Local Climate Policy," Local Environment, Vol. 9, No. 4, 2004, 325-336. doi:10.1080/1354983042000246252

[16] M. M. Betsill, "Localizing Global Climate Change: Controlling Greenhouse Gas Emissions in US Cities,” Belfer Center for Science and International Affairs (BCSIA), Discussion Paper 2000-20, Kennedy School of Government, Harvard University, Cambridge, 2000.

[17] C. Kousky and S. H. Schneider, "Global Climate Policy: Will Cities Lead the Way?” Climate Policy, Vol. 3, No. 4, 2003, pp. 359-372.

[18] T. Linstroth and R. Bell, "Local Action: The New Paradigm in Climate Change Policy," University of Vermont Press, Burlington, 2007.

[19] N. Lutsey and D. Sperling, "America's Bottom-Up Climate Change Mitigation Policy,” Energy Policy, Vol. 36, No. 2, 2008, pp. 673-685. doi:10.1016/j.enpol.2007.10.018
[20] J. B. Wiener, "Think Globally, Act Globally: The Limits of Local Climate Policies," University of Pennsylvania Law Review, Vol. 155, No. 6, 2007, pp. 101-119.

[21] M. Lubell, R. Feiock and S. Handy, "City Adoption of Environmentally Sustainable Policies in California's Central Valley," Journal of the American Planning Association, Vol. 75, No. 3, 2009, pp. 293-308. doi:10.1080/01944360902952295

[22] K. Engel and B. Orbach, "Micro-Motives and State and Local Climate Change Initiatives," Harvard Law \& Policy Review, Vol. 2, 2008, pp. 119-137.

[23] S. Zahran, S. D. Brody, A. Vedlitz, H. Grover and C. Miller, "Vulnerability and Capacity: Examining Local Commitment to Climate Change Policy," Environment and Planning C: Government and Policy, Vol. 26, No. 3, 2008, pp. 544-562. doi:10.1068/c2g

[24] D. Pitt, “The Impact of Internal and External Characteristics on the Adoption of Climate Mitigation Policies by US Municipalities," Environment and Planning C: Government and Policy, Vol. 28, No. 5, 2010, pp. 851-871. doi:10.1068/c09175

[25] I. Vasi, “Organizational Environments, Framing Processes, and the Diffusion of the Program to Address Global Climate Change among Local Governments in the United States," Sociological Forum, Vol. 21, No. 3, 2006, pp. 439-466. doi:10.1007/s11206-006-9023-5

[26] S. Zahran, H. Grover, S. Brody and A. Vedlitz, "Risk, Stress and Capacity: Explaining Metropolitan Commitment to Climate Protection," Urban Affairs Review, Vol. 43, No. 4, 2008, pp. 447-474. doi: $10.1177 / 1078087407304688$

[27] US Census Bureau, “American Community Survey 20052009 5-Year Estimates,” 2011. http://www.census.gov/acs/www/

[28] US Environmental Protection Agency, “AirData: Access to Monitored Air Quality Data from EPA's Air Quality System,” 2011. http://www.epa.gov/airquality/airdata/ad_data_daily.html

[29] National Center for Charitable Statistics, "The Urban Institute Search Tool,” 2011. http://nccsdataweb.urban.org/PubApps/search.php

[30] Pew Center on Global Climate Change, "Climate Change 101: State Action,” 2011. http://www.c2es.org/docUploads/climate101-state.pdf

[31] The New York Times, "Election Results 2008: President Map," 2008. http://elections.nytimes.com/2008/results/president/map.h tml 